THE UNIVERSITY OF CHICAGO LAW REVIEW

\title{
VOTING ON CONSTITUTIONAI CONVENTIONS AND AMENDMENTS
}

\author{
KenNeth C. SEARS*
}

$1{ }^{1}$ EARLY every voter in Illinois with a progressive spirit will admit that the present Mllinois Constitution is either in need of amendment or revision. It is also perfectly true that it is extraordinarily difficult to secure either an amendment or a revision. No amendment except one for a bond issue has been adopted since r904. The proposed revision in I922 was defeated, despite many good changes that were prepared, only to be submitted as a unit for a single vote. The major factors that are forcing the state to be politically backward are the provisions in the present state constitution for its revision and amendment. ${ }^{x}$ The powerful defect in those provisions is the requirement that a majority of all who in any manner become voters at a general election must approve of a proposal for an amendment or constitutional convention before the proposal is adopted. It is not sufficient that the favorable vote is a majority of those who voted upon the proposal. Thus, a person who becomes a voter in the sense that he takes a ballot and votes for one person or proposition thereon but fails to vote on a proposal for a constitutional amendment or convention is nevertheless the equivalent of a negative

* Professor of Law, University of Chicago Law School.

I " $\$$. Whenever two-thirds of the members of each house of the General Assembly shall, by a vote entered upon the journals thereof, concur that a Convention is necessary to revise, alter or amend the constitution, the question shall be submitted to the electors at the next general election. If a majority voting at the election vote for a convention, the General Assembly shall at the next session, provide for a convention, to consist of double the number of members of the senate, to be elected in the same manner, at the same places, and in the same districts. .....

" "§ 2. Amendments to this Constitution may be proposed in either House of the General Assembly, and if the same shall be voted for by two-thirds of all the members elected to each of the two houses, such proposed amendments, together with the yeas and nays of each house thereon, shall be entered in full on their respective journals, and said amendments shall be submitted to the electors of this State for adoption or rejection, at the next election of members of the General Assembly, in such manner as may be prescribed by law. The proposed amendments shall be published in full at least three months preceding the election, and if a majority of the electors voting at said election shall vote for the proposed amendments, they shall become a part of this Constitution. But the General Assembly shall have no power to propose amendments to more than one article of this Constitution at the same session, nor to the same article oftener than once in four years." Constitution of Hlinois (I870) art. XIV. 
voter on such constitutional proposal. In this way a number of proposed constitutional amendments in Illinois which have received large majorities of those voting upon the amendments have nevertheless failed of adoption because of a failure to receive a "constitutional" majority, i.e., a majority of all who voted for anybody or anything on the particular occasion. ${ }^{2}$ The problem is to find a way out of this constitutional morass. To do this it will be helpful to know how we happened to get into the morass.

Despite the obvious fact that those who drafted the constitution in I870 were very conservative and sure of themselves it does not seem fair or accurate to accuse them of a desire to make their constitution practically incapable of amendment. In 1870 the mechanics of voting were very different from those of today. Therein is the difference between a constitution that could be amended when such was the majority sentiment in the state and a constitution that can only be amended when the sentiment is overwhelming or approaches the universal. In 1870 there was no official ballot in this state. Ballots were printed by the parties and handed to the voters by party workers at the polls. Consequently, if a party organization printing ballots was favorable to a proposed amendment a statement to this effect was printed on that party's ballot. The person who expressed himself by using that ballot voted in favor of the amendment unless he used some diligence to "scratch" that statement from the ballot. True, another party could take the contrary action or, do what was the same in effect, omit any statement of the proposal from its ballot. ${ }^{3}$ But statistics show that all five amendments proposed during the period from I870 to I89x, until a. law provided for an official ballot, were adopted. 4 With this law in I89I there came an end to the method of voting with which those who framed our constitution were familiar.

${ }^{2}$ See Constitutional Convention Bulletins, 180 , and Illinois Blue Book (1933-34), 36-38.

3 "The printed ballot has been in use in Illinois since 1848 . Until $189 \mathrm{r}$, however, the printing of ballots devolved upon political parties, and the parties could either: ( $(1)$ omit all mention of the proposed amendment from their ballots; (2) print the measure in such a way as to leave the voter an option to vote for or against it, or (3) to print either the affirmative or the negative of the measure. The third alternative was the one usually taken advantage of, and every straight party vote was therefore cast in accordance with the party action which appeared upon the ballot. Upon a ballot of this character it was easily possible to cast upon a measure substantially the same vote as that cast by regular voters upon candidates. . . ." Constitutional Convention Bulletins, $177-r 78$.

See also an article by C. O. Gardner in 5 Am. Pol. Sc. Rev. 394 (Ig08).

4 See supra note 2. The official ballot law appears in Laws of Illinois for I89r, Io7-r2r. See particularly $\$ \S \mathrm{I} 6$ and $\mathrm{I4}$. The latter provided in part: "If a constitutional amendment or other public measure is submitted to a vote, such question shall be printed upon the ballot after the list of candidates. ...." 
From 189I to 1899 proposals for constitutional amendments were placed on the official candidates' ballot in a way that did not attract particularly the attention of the voters. Worse, it was necessary for every voter to mark his preference for the proposal if he were to be counted in favor of it. Otherwise, under the constitutional provision, he would be counted as voting in the negative. The results were disastrous. During this second period none of the three constitutional proposals was adopted and none received in excess of twenty-five per cent of the votes cast at the election counting both the yeas and the nays. The remaining seventy-five per cent and upward represented voters who expressed no opinion but were nevertheless counted as voting in the negative. ${ }^{5}$ Thus, in this period the people of Illinois, as far as proposed constitutional changes were concerned, were under the complete domination of the indifferent and ignorant voters. This great change appears to have been nothing else except an unforeseen result of a change from an unofficial to an official ballot of a particular sort.

The sad fact is that Illinois has not yet managed to remove this handicap in a satisfactory way. In I899 a law provided that proposals for constitutional amendments and conventions should be submitted on a separate ballot, the "little" ballot. It was thought that this would attract the attention of the voters to a greater extent than such a proposition on the candidates' ballot. This proved to be true, but the difference in important results has not been impressive. ${ }^{6}$ Illinois in the main is still controlled in such voting by the indifferent and ignorant. We are still in the morass.

Governor Emmerson made an attempt to emerge in 1929 when he persuaded the General Assembly to place constitutional proposals on the candidates' ballot. He and others hoped that by providing that such - proposals should be placed in a separate column on the left side of the ballot no voter would fail to see it. The law has not received a long test, but results to date indicate that the situation is somewhat worse than that under the law of 1899 providing for the separate or "little" ballot." As a matter of fact the ballot as printed in Chicago, at least, is very large

5 See Constitutional Convention Bulletins, $180-18 x$, and Illinois Blue Book (1933-34), 37.

${ }^{6}$ See Laws of Illinois for $I 899$, $15 x$. Observe that section 16 was the section amended but that $\S I_{4}$ was not mentioned. Compare supra note 4 .

Between 1899 and 1929 five proposals to amend the constitution were submitted. Only two of these received the required constitutional majority and one of these was a bond issue. No proposal for a material change in the constitution has been adopted since Ig04. A proposal for a constitutional convention carried in rgr8. See Illinois Blue Book (1933-34), 37-38.

${ }_{7}$ See Laws of Illinois for $1929,392-394$. $\S \mathrm{x}_{4}$ was amended by eliminating the words set forth in supra note 4 . $\$ 16$ was amended so that it ceased to apply to proposals for constitutional amendments but continued to regulate voting on "public measures." $\$ 15 \frac{1}{2}$ was added and it provided for the submission "upon the same ballot as the names of candidates for State 
and constitutional propositions have not been printed in a manner that really arrested the attention of the careless and indifferent voter. Under statutory authority which could be conferred, the type could be larger, printed hands could point to the proposal, color type could be used, or the proposition could be placed across the top of the ballot, or between the Democratic and Republican columns. Whether any of these suggested variations would produce better results must remain a matter of speculation. As matters now appear the Emmerson law is a failure. What will be the next experiment?

Experimentation seems to be a hateful word to many minds these days, but in this situation we must experiment further or submit to what seems to be nearly a hopeless situation. Senator Ward introduced in the present session of the General Assembly Senate Bill 8I which would return to the law of 1899 , the separate or "little" ballot. ${ }^{8}$ His bill passed the Senate on March 20 and at this writing is pending in the House of Representatives. But why should we go back to a method that has been proved so thoroughly to be so clearly inadequate? Why not hope that a successful method can be evolved by trial and error? Senator Mayor has introduced three bills which express such a hope. Senate Bill 280, with Senate Bills 278 and 279 as minor companion bills, seeks to weld together the Emmerson law and the proven advantages in the mechanics of voting prior to I89I, the year our troubles started. 9 The separate column on the left of

and other offices to be voted at such election in a separate column at the left of the names of all candidates for office." Observe that this section does not in terms apply to proposals for assembling a constitutional convention but in Chicago, at least, it was thought to control the voting on the proposal for the purpose that was submitted at the November, 1934, election.

Under the Emmerson law in I930 a proposal, which many friends of taxation reform could not support, to amend the revenue clause of the constitution failed to obtain even a majority of those voting on the proposal, to say nothing of a majority of the total vote cast at the election.

In 1932 another submission of the so-called gateway amendment received $1,080,54$ I favorable votes as against only 275,329 negative votes. Yet the proposal which received a majority. of 805,212 was defeated by a "constitutional" majority of 652,423 . Less than thirty-nine per cent of the $3,465,927$ voters at the election voted on the proposal. See Illinois Blue Book (r93334), 39, 700.

The proposal in 1934 for a constitutional convention which received a majority of $105, \mathrm{I} 42$ of those voting on the proposition was far short of a "constitutional" majority.

${ }^{8}$ The only difference between Senator Ward's bill and the law enacted in $r 899$ is that Senaator Ward's bill confines itself to proposals for constitutional amendments while the separate ballot law of $r 899$ included proposals known as "public measures."

9 Senate Bills 278 and 279 have been "Tabled." In place of them Senate Bill 357 has been introduced by Senator Mayor.

On May 8, I935, word was received that Senate Bills 280 and 357 had passed the Illinois Senate. 
the candidates' ballot would remain as it is now. There any voter may vote for or against any constitutional proposition. In addition, any party which in its state convention adopts a resolution approving the constitutional proposal will thus cause an affirmative statement of that proposal to appear at the foot of its party column and a vote in the party circle (straight ticket) will be a vote in favor of the proposition unless elsewhere on the ballot an inconsistent vote is marked. This inconsistent vote normally would appear, it seems, in the column on the left of the ballot, but it might appear by making a cross (X) opposite a negative statement of the same proposal, if there happens to be such, at the foot of some other party column. It is expressly provided that a party in its state convention may adopt a resolution in opposition to a constitutional proposal; if it does then a cross $(\mathrm{X})$ in the party circle of that party column will be a vote against the proposal unless there is an inconsistent expression elsewhere on the ballot as heretofore explained.

An objection may be made to Senator Mayor's bills that they will afford an opportunity for political parties to work at cross purposes; that the approval of a proposal by the convention of one party will be offset by the disapproval by the convention of another party and vice versa. There appear to be two answers to this objection. In the first place it should not be forgotten that an essentially similar scheme of voting worked out prior to I89I so that five proposed constitutional amendments out of five were adopted by the voters. The second answer is that under the present constitution as interpreted by the Mllinois Supreme Court in People v. Stevenson, ${ }^{10}$ every voter at an election is counted as voting in the negative on constitutional proposals unless he distinctly casts an affirmative vote. So, the disapproval of a proposal by a party convention is no more adverse to constitutional reform than a refusal by a convention to adopt a resolution either for or against a constitutional proposal. Then it should not be forgotten that if a party convention adopts a resolution against a proposal a member of that party voting in the party circle can cast a vote in favor of the proposal by making an " $X$ " opposite the word "yes" in the separate column on the left or by making an " $\mathrm{X}$ " in the blank space opposite the affirmative statement of the proposal at the foot of another party column provided, of course, some party with a column has taken affirmative action. Either of the latter methods of voting takes precedence over the " $\mathrm{X}$ " in the party circle.

The following statistics of the votes cast at the last November election show some possibilities for effectiveness in the bills proposed by Senator

so 28 I Ill. I7, II7 N.E. 747 (I9I7). 
Mayor. This information was secured from the Board of Election Commissioners of Chicago. The wards selected for examination probably are wards with a higher percentage of "straight" party votes than the average.

If Senator Mayor's bills become laws those in Illinois who are interested in constitutional reform may renew their hope. With such law a "gateway" amendment emerges from the dream stage. It has been presented four times and is better understood and appreciated, apparently, than any other proposal that has been made. But we should be careful to secure

\begin{tabular}{|c|c|c|c|c|c|c|c|}
\hline \multirow{2}{*}{ WARD } & \multirow{2}{*}{$\begin{array}{c}\text { TotaI } \\
\text { Vote CAST }\end{array}$} & \multicolumn{2}{|c|}{$\begin{array}{c}\text { Vote oN } \\
\text { CoNst. CoNy. }\end{array}$} & \multirow{2}{*}{ ТотаL } & \multirow{2}{*}{$\begin{array}{l}\text { StratGit } \\
\text { Democ. } \\
\text { Vote }\end{array}$} & \multirow{2}{*}{$\begin{array}{l}\text { Straight } \\
\text { REPUB. } \\
\text { Vote }\end{array}$} & \multirow{2}{*}{$\begin{array}{l}\text { STRATGHT } \\
\text { Votes } \\
\text { TotaI }\end{array}$} \\
\hline & & "Yes" & "No" & & & & \\
\hline $\begin{array}{l}\text { Ist } \\
24^{\text {th }} \\
2 g^{\text {th }} \\
\text { 3oth } \\
35^{\text {th }} \\
3^{8 \text { th }}\end{array}$ & $\begin{array}{l}14,443 \\
23,312 \\
24,539 \\
27,520 \\
23,883 \\
27,972\end{array}$ & $\begin{array}{r}7,723 \\
12,951 \\
9,795 \\
7,106 \\
6,133 \\
8,823\end{array}$ & $\begin{array}{l}r, 788 \\
1,456 \\
2,922 \\
4,728 \\
4,986 \\
4,449\end{array}$ & $\begin{array}{r}9,511 \\
14,407 \\
12,717 \\
11,834 \\
11,119 \\
13,272\end{array}$ & $\begin{array}{l}\text { I1,069 } \\
18,423 \\
15,911 \\
14,090 \\
12,661 \\
13,824\end{array}$ & $\begin{array}{l}2,027 \\
1,071 \\
3,753 \\
4,259 \\
3,824 \\
6,017\end{array}$ & $\begin{array}{l}13,096 \\
19,494 \\
19,664 \\
18,349 \\
16,485 \\
19,841\end{array}$ \\
\hline
\end{tabular}

a different type of a "gateway" amendment than any offered heretofore. It is rather amazing that heretofore every such proposal has been practically confined to changing only one defect in our present amending clause, article XIV, section 2. This prohibits voting upon changes in more than one article of our present state constitution at any one general election. The "gateway" proposals in the past in general have been limited to changing this feature. ${ }^{\mathrm{x}}$ This is not the provision in our present amending clause that is causing the significant trouble. That is being caused by the

"The proposal of $189 \mathrm{r}$, aside from one insignificant change, that was perhaps the crror of a copyist, merely substituted the word "two" for the word "one" before the word "article" which in turn was changed to the plural. See Laws of Illinois for 1891,217 . The constitutional provision is copied in supra note $\mathrm{I}$.

The proposal for 1895 omitted the insignificant change. It substituted the word "three," instead of the word "two," for the word "one." Then it changed the next to the last word in the amending clause from "four" to "two." See the Laws of Illinois for 1895,331 .

The proposal of 1923 omitted the insignificant change and otherwise made the same changes as the proposal of 1891 . Then there was added the following: "provided, that no constitutional amendment shall be proposed or voted on during the time that the United States is engaged in war or within one year following the declaration of peace." This added restriction was motivated, presumably, by resentment caused by the eighteentl amendment to the federal constitution. See Laws of Illinois-for 1923, 632 .

The proposal of 193 I followed the one of I923 except that the word "three" instead of the word "two" was substituted for the word "one." The added restriction in the proposal of rg23 was omitted. See Laws of Mllinois for 193I, 9r6. 
provision that in order to adopt a proposed amendment it is necessary to secure for the proposal "a majority of the electors voting at said election," i.e., "at the next election of members of the General Assembly." What good can be accomplished by making it theoretically possible to amend two or three articles of our constitution at one election when it has been impossible to secure the adoption of even one amendment for thirty years, barring one bond issue? If we ever vote upon a gateway amendment again we should not deceive ourselves. We should change the provision as to the majority required for adoption. That is the first essential. Other changes in our amending clause are in order but the main difficulty should not be disregarded as it has been in the past. It should be sufficient to adopt a proposed amendment that it receive a majority of all votes cast upon that proposal. If Senator Mayor's bills lead us to that reform we can then consider an abandonment of the scheme of automatic voting which to a certain extent they will give us. ${ }^{\mathbf{2}}$

${ }^{22}$ In State Government (Dec. I934), 263, there is a tabulation of the amending and revising features of the constitutions in the forty-eight states. From this it appears that only nine states, including Illinois, require a majority of the votes at an election to adopt an amendment. Thirty-seven states are satisfied with a requirement that there must be a majority on the question in favor of the amendment. Delaware has no provision for a popular vote and New Hampshire's constitution can be amended only in convention. 